\title{
Nutritional and anthropometric profile of adolescent volleyball athletes*
}

\author{
Tania Abreu de Almeida ${ }^{1}$ and Eliane Abreu Soares ${ }^{2}$
}

\begin{abstract}
Women's participation in volleyball began in 1928. In 1944, the first Brazilian volleyball championship happened. Flexibility, strength, power, agility and aerobic fitness are all necessary to be a master in this sport. Women's participation in sport activity has increased. However, there are only a few studies in Brazil about nutrition assessment, especially amongst female volleyball players. Therefore, the aim of this study is to assess the dietetic and anthropometric profiles of 25 female adolescent volleyball players of Rio de Janeiro (15-20 years old). Anthropometric assessment was obtained by body mass, stature, skinfold and circumference measurements. Prospective 3-day records, that include two weekdays and one weekend day were analyzed by a Brazilian nutrition software (CIS/EPM, 1993) to obtain the nutrient intake and the results were compared to the American recommendations. The results of anthropometric evaluation showed that athletes had body mass of $64.35 \pm 6.12 \mathrm{~kg}$, stature of $1.74 \pm 0.06 \mathrm{~m}$ and fat mass of $20.51 \pm 2.43 \%$. Diets consisted of high energy and protein intake, and low carbohydrate intake. The consumption of calcium, folate and vitamin $\mathrm{E}$ was below the recommendations. Since these athletes are going through a period of intense growth and development associated with rigorous training, it becomes, therefore, necessary for them to re-
\end{abstract}

1. Nutricionist and specialist in Nutrition and Physical activity - Instituto de Nutrição, Universidade do Estado do Rio de Janeiro.

2. Nutricionist, Associate Professor - Instituto de Nutrição, Universidade do Estado do Rio de Janeiro (UERJ) e Instituto de Nutrição, Universidade Federal do Rio de Janeiro (UFRJ).

Received in 3/7/02

Approved in 21/50/03

Correspondence to:

Rua Marquês de Abrantes, 177 - 1.104

22230-060 - Rio de Janeiro, RJ

E-mail: t_abreu_de_almeida@hotmail.com ceive individualized nutritional orientation to improve their performance and quality of life.

Key words: Adolescent. Volleyball. Nutritional assessment. Anthropometric assessment. Nutrition.

\section{INTRODUCTION}

Volleyball was created in 1895 by William Morgan. Women started to play it only in 1928. In 1916, volleyball gets to Brazil, brought by the Youth Men Christian Association, and in 1944 the First Brazilian Championship was held ${ }^{1}$.

Volleyball is a sport that alternates aerobic and anaerobic activity, thus requiring muscular strength and power capability. The athlete must possess flexibility, strength, power, agility and aerobic fitness to practice it $^{2}$.

During adolescence, individuals undergo significant growth and maturation, and unique changes take place in the body, thus causing an increase of nutritional needs. As adolescent athletes have energetic needs that are different from the needs of adult athletes, one should pay heed not only to energetic suitability, but also to the intake of protein and fluids before, during and after the exercise ${ }^{3}$.

Few are the studies ${ }^{3-9}$ that assess nutritional profile of young female volleyball athletes, with their anthropometric features and checking nutritional suitability of macro and micronutrients, according to the recommended guidelines.

The purpose of this research was, therefore, to assess dietary and anthropometric profiles of adolescent athletes from two clubs in the city of Rio de Janeiro.

\section{METHODOLOGY}

\section{Subjects}

Twenty-five volleyball female (15-19 years) athletes of two clubs in the city of Rio de Janeiro (Botafogo Futebol Clube and Fluminense Futebol Clube) were investigated. Their parents signed an informed consent form allowing their participation in the research. 


\section{Dietary assessment}

The record of their intake during three days, consecutives or not, being one a weekend day, and a questionnaire of intake frequency, to assess the dietary profile of the subjects under investigation were used. These are the most used dietary assessment methods to calculate quantitative and qualitative energetic intake of an individual or a population $^{10}$.

In spite of being a subjective method, prone to psychological tendencies, the food-intake record is broadly used. To apply this method, the subject must record all ingested food at a particular period of time, and its respective amount ${ }^{10}$.

The ingested food was recorded following home-style measurement, and further converted into grams and milliliters, according to Pinheiro et al. ${ }^{11}$

Nutrients were assessed by a nutrition support software, designed by the Information Technology Center from Escola Paulista de Medicina ${ }^{12}$. The athletes' dietary adequacy for the ingested nutrients was done by comparing it to American nutritional recommendations ${ }^{13,14}$.

In the questionnaire of nutritional frequency, food was divided into nine groups: meats, dairy, eggs, cereals, vegetables, leaves, fruits, fat, and miscellaneous, in order to qualitatively assess the athletes' food intake. The questionnaire of nutritional frequency is used to measure the quality of an individual's "habitual" intake. This questionnaire is valid only if its results are compared to another dietary assessment method ${ }^{15}$. Thus, to enhance accuracy of nutritional assessment, a number of methods are used simultaneously ${ }^{16}$.

To calculate total energetic expenditure, expenditure at all activities carried out by the athletes over 24 hours, and hours or sleep per night ( 8 hours) were taken into account; main activity, study (4.5 hours a day); physical/tactical training ( 2.5 hours a day); other daily activities ( 9 hours a day $)^{17}$.

\section{Anthropometric assessment}

Total body mass, stature and circumferences of arms, abdomen, hip, thigh, and the skinfolds triceps, biceps, chest, subscapular, suprailiac, abdominal, and thigh were assessed. These variables were measured by a single, anthropometry-specialist evaluator.

To measure total body mass, one used a digital scale $\mathrm{Seca}^{\circledR}$, maximum capacity of $150 \mathrm{~kg}$, and the athletes were in barefoot, and with as little clothing as possible. To determine stature, a portable stadiometer Soehnle ${ }^{\circledR}$ was used. Upon assessment, the athletes remained in a standing position, barefooted, with feet close together and in inhaling apnea, the head following the Frankfurt plan ${ }^{18}$.
Perimeters were measured with a metal anthropometric tape Sanny ${ }^{\circledR}$, with $0.1 \mathrm{~cm}$ increments, according to Fernandes ${ }^{18}$. Skinfolds were measured with a Harpenden ${ }^{\circledR}$ caliper. Measurements were on the right side of the body, reference points were marked and skinfolds were pinched with the thumb and indicator fingers. Three measurements were made and the mean was recorded. All measurements were made at the same time, before practice. Body density was calculated according to Sloan protocol ${ }^{19}$, with the measures of triceps and suprailiac skinfolds.

The proportion of body fat was calculated according to Brozek equation (1963) ${ }^{19}$.

\section{Statistical analysis}

For statistical analysis one used the non-parametric normality test Sign test to assess the investigated nutrients. Only for mineral calcium we used the normality Student's $t$ test.

\section{RESULTS}

\section{Characterization of the sample}

The assessed athletes' mean age was $16 \pm 3.55$ years, who practiced volleyball for five years and trained for two and a half hours a day, in average, five days a week. Average sleep time was of eight hours a day.

From the 25 athletes, only one was not a student. Twenty-two were in high school, two were in college.

All athletes menstruated at the time of the research, and mean age for menarche was around 12 years of age (12.38 \pm 1.42 years). Athletes had monthly menses.

No athlete mentioned use of vitamins, food supplements or any medication during the period of investigation.

\section{Dietary assessment}

Dietary assessment was done through a three-day foodintake record, and a questionnaire of food frequency.

Daily calories intake was around 3,945 $\pm 633 \mathrm{kcal}$ (table 1). Proportional distribution of macronutrients in relation to total energetic value was $20 \%$ for proteins, $48 \%$ for carbohydrates, and $32 \%$ for lipids (figure 1).

There was significant difference in the daily intake of the studied nutrients, such as calcium, vitamin E and folate, when compared to American guidelines (table 2).

There was significant difference for intake of calcium, vitamin $\mathrm{E}$ and folate, with variation coefficients lower than 0.001 and 0.002 , respectively, when compared to American guidelines ${ }^{13,14}$.

No significant differences in food intake were found among athletes of both clubs (tables 3 e 4). 
TABLE 1

Energy and macronutrients intake of the volleyball players

\begin{tabular}{lcccc}
\hline \multicolumn{1}{c}{ Variables } & Mean \pm SD & Median & Minimum & Maximum \\
& & & & \\
Energy (kcal/d) & $3,945 \pm 633$ & 3,749 & 1,092 & 4,817 \\
kcal/kg/d & $37 \pm 30$ & 32 & 18 & 73 \\
Total protein (g/d) & $151 \pm 25$ & 148 & 46 & 184 \\
g/kg/day & $2.42 \pm 0.33$ & 2.33 & 0.81 & 2.87 \\
Carbohydrates (g/d) & $418 \pm 77$ & 429 & 150 & 567 \\
g/kg/day & $6.55 \pm 1.11$ & 6.41 & 2.10 & 9.75 \\
Lipids (g/day) & $118 \pm 26$ & 112 & 37 & 155 \\
\hline
\end{tabular}

TABLE 2

Micronutrients intake of the volleyball players

\begin{tabular}{lcccc}
\hline \multicolumn{1}{c}{ Nutrients } & Mean \pm SD & Median & Minimum & Maximum \\
Niacin $(\mathrm{mg})$ & $22.65 \pm 13.72$ & 23.22 & 2.65 & 38.72 \\
Vitamin $\mathrm{B}_{6}(\mathrm{mg})$ & $13.69 \pm 19.15$ & 5.44 & 0.28 & 42.29 \\
Folate $(\mu \mathrm{g}) * *$ & $244.98 \pm 159.78$ & 200 & 39.59 & 463 \\
Vitamin C $(\mathrm{mg})$ & $119.73 \pm 45.64$ & 100 & 7.03 & 430.96 \\
Vitamin E $(\mathrm{mg}) * *$ & $15.60 \pm 14.81$ & 10.74 & 1 & 36.64 \\
Calcium $(\mathrm{mg}) *$ & $1,199.17 \pm 315.25$ & 1,204 & 237.12 & $1,824.39$ \\
Iron $(\mathrm{mg})$ & $27.38 \pm 9.35$ & 28 & 8.11 & 35.44 \\
Zinc $(\mathrm{mg})$ & $12.73 \pm 9.35$ & 13 & 0.60 & 20.16 \\
\hline$* \mathrm{p}<0.001 ; * * \mathrm{p}<0.002$ & & & & \\
\hline
\end{tabular}

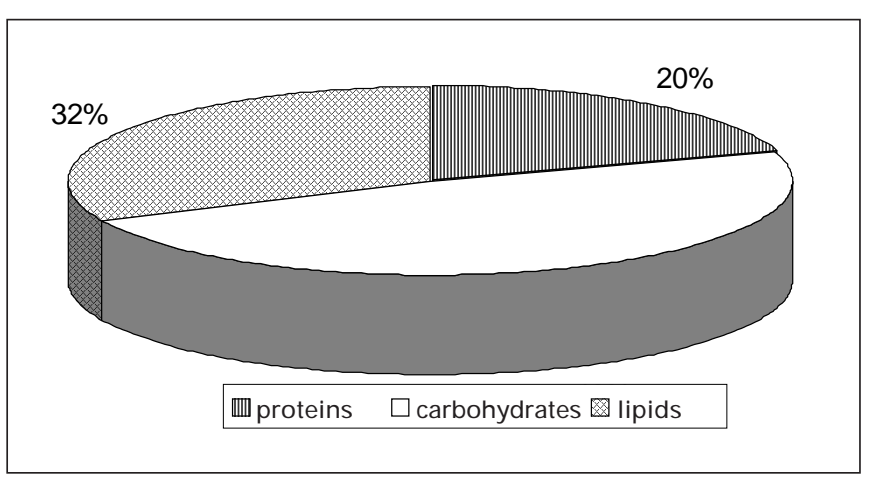

Fig. 1 - Percentage of the macronutrients in relation to the total energetic value of the volleyball players' diets

\section{Anthropometric assessment}

The athletes' mean total body mass was $64.35 \pm 6.12 \mathrm{~kg}$; stature, $174 \pm 0.06 \mathrm{~cm}$; proportion of fat, 20.51. Measures of skinfolds and circumferences are presented in table 5 .

\section{DISCUSSION}

Studies have shown that athletes, particularly females, have an inadequate nutritional intake when compared to their energetic expenditure ${ }^{3,4}$. Such energetic inadequacy is negatively reflected in the intake of vitamins and minerals 5 .

To calculate total energetic expenditure, energetic expenditure of all activities performed by the athletes over 24 hours was taken into consideration. Mean result was of $2,500 \mathrm{kcal} / \mathrm{day}$, in accordance with Ainsworth's method ${ }^{17}$. The athletes had a daily average intake of $3,749 \mathrm{kcal} /$ day, which is $150 \%$ of the energetic amount, calculated by that method.

Adolescents need a higher protein intake than adults. The ideal protein intake for growth, physical performance and enhancement of muscular mass is around $1.5 \mathrm{~g} / \mathrm{kg} / \mathrm{day}^{20,21}$. Daily intake of proteins by the athletes was $2.4 \mathrm{~g} / \mathrm{kg} /$ day, an adequacy of $160 \%$, equivalent to $20 \%$ of total energetic value. This is explained by the high frequency of proteinrich food, such as chicken, beef and egg (table 6).

Lemon (1997) ${ }^{21}$ suggests that high-protein diets do not necessarily enhance muscular mass, and they may also increase urine loss of calcium, play an atherogenic role as they are associated to animal fat (which is rich in saturated fatty acids), and increase loss of fluids, due to urinary excretion to eliminate the additional nitrogen found in this 


\begin{tabular}{lcc}
\hline \multicolumn{3}{c}{ TABLE 3 } \\
\multicolumn{3}{c}{$\begin{array}{c}\text { Energy and macronutrients intake } \\
\text { of players from both clubs }\end{array}$} \\
\hline \multicolumn{1}{c}{ Variables } & Botafogo & Fluminense \\
& (mean \pm & $\begin{array}{c}\text { (mean } \pm \\
\text { standard } \\
\text { deviation) }\end{array}$ \\
& standard & \\
Energy (kcal/d) & $23,090 \pm 915.90$ & $2,138.16 \pm 2,159$ \\
Proteins (g/d) & $86.00 \pm 21.23$ & $83.76 \pm 46.20$ \\
g/kg/d & $1.35 \pm 0.39$ & $1.32 \pm 0.81$ \\
Carbohydrates (g/d) & $322.00 \pm 159.00$ & $220.92 \pm 144.09$ \\
g/kg/d & $5.02 \pm 3.04$ & $3.44 \pm 2.43$ \\
Lipids (g/d) & $89.00 \pm 37.00$ & $65.97 \pm 53.90$ \\
\hline
\end{tabular}

There was no significant difference of energy consumption from macronutrients intake between the two groups.

type of diet. Fluid replacement should be more carefully monitored when there is an intake of protein-rich diets.

As it is highly used for moderate intensity exercises, carbohydrate intake is associated to physical performance, being the highest source of energy for the muscle under exertion $^{22}$. Factors such intensity and duration of exercise, the influence of physical training and diet may change intake needs of this nutrient ${ }^{22}$. The recommendation for those who practice physical exercises is around 55 to $60 \%$ of carbohydrates of the overall energetic value. Recommendations are to increase carbohydrate intake to 65 to $75 \%$ of total energetic intake for endurance athletes and individuals who have daily practice. The athletes in our study had an average carbohydrate intake of $47 \%$ of the total energetic amount, a lower proportion than the recommended for athletes under growing process and daily practice. To maximize muscular glycogen storage, carbohydrate intake of 6 to $10 \mathrm{~g} / \mathrm{kg} /$ day ${ }^{20}$ is recommended. In our study, we found a mean of $6.41 \mathrm{~g} / \mathrm{kg} / \mathrm{day}$, ranging from 2.1 to $9.75 \mathrm{~g} / \mathrm{kg} / \mathrm{day}$.

To maintain concentration and replacement of muscular glycogen, carbohydrate intake should be of 500-800 g/day. High supplies of muscular glycogen produce a higher energetic reserve for aerobic and anaerobic activities, leading to a higher resistance and delaying fatigue to arise. The study revealed that our athletes had a mean carbohydrate intake of $429 \mathrm{~g} / \mathrm{day}$, ranging from 150 to $570 \mathrm{~g} / \mathrm{day}, 71 \%$ of the average recommended amount ${ }^{20}$.

\begin{tabular}{lcc}
\hline \multicolumn{3}{c}{$\begin{array}{c}\text { TABLE 4 } \\
\text { Micronutrients intake of volleyball } \\
\text { players from different clubs }\end{array}$} \\
\hline Micronutrients & Botafogo & Fluminense \\
& & \\
Niacin $(\mathrm{mg})$ & $14.10 \pm 8.32$ & $10.77 \pm 9.87$ \\
Vitamin B6 (mg) & $2.22 \pm 4.58$ & $4.80 \pm 22.23$ \\
Folate $(\mu \mathrm{g})$ & $82.01 \pm 53.77$ & $94.18 \pm 68.72$ \\
Vitamin C (mg) & $108.74 \pm 210.86$ & $67.18 \pm 63.52$ \\
Vitamin E (mg) & $4.19 \pm 3.78$ & $2.94 \pm 3.32$ \\
Calcium (mg) & $785.17 \pm 397.3$ & $889.20 \pm 755.94$ \\
Iron $(\mathrm{mg})$ & $12.21 \pm 5.5$ & $12.62 \pm 7.29$ \\
Zinc $(\mathrm{mg})$ & $7.28 \pm 3.75$ & $5.09 \pm 5.01$ \\
\hline
\end{tabular}

There was no significant difference of energy consumption from micronutrients intake between the two groups.

TABLE 5

Anthropometric parameters of the volleyball players

\begin{tabular}{lr} 
Skinfolds $(\mathbf{m m})$ & Mean \pm SD \\
Triceps & $17.55 \pm 3.87$ \\
Biceps & $8.07 \pm 2.42$ \\
Chest & $10.57 \pm 2.66$ \\
Subscapular & $13.74 \pm 3.88$ \\
Suprailiac & $12.95 \pm 4.13$ \\
Abdominal & $21.01 \pm 5.94$ \\
Thigh & $26.02 \pm 6.43$ \\
Circumferences (cm) & Mean \pm SD \\
Arm & $26.01 \pm 1.85$ \\
Abdomen & $76.17 \pm 5.18$ \\
Thigh & $52.29 \pm 3.30$ \\
Hip & $97.48 \pm 3.72$ \\
\hline
\end{tabular}

TABLE 6

Food often eaten by volleyball athletes from Botafogo and Fluminense clubs

\begin{tabular}{lrccc}
\hline \multicolumn{1}{c}{ Food } & Daily & 6-4 times/week & 3-2 times/week & 1 time/ week \\
Chicken & 1 & 8 & 14 & 1 \\
Beef & 3 & 6 & 10 & 4 \\
Egg & 1 & 4 & 7 & 11 \\
Milk & 11 & 1 & 5 & 4 \\
Cheese & 5 & 5 & 9 & 1 \\
Beans & 12 & 5 & 4 & 2 \\
Rice & 15 & 7 & 1 & 0 \\
Bread & 16 & 2 & 3 & 0 \\
Cookie & 7 & 3 & 3 & 4 \\
Lettuce & 2 & 6 & 7 & 2 \\
Potato & 4 & 4 & 4 & 3 \\
Banana & 9 & 7 & 2 & 6 \\
Oil & 24 & 0 & 0 & 0 \\
Candy & 3 & 7 & 3 & 0 \\
Chocolate & 0 & 1 & 7 & 4 \\
\hline
\end{tabular}


Low-carbohydrate diets may compromise physical performance, causing negative effects in those who practice physical activities ${ }^{23}$. Therefore, particularly after practice and competitions, it is advisable the intake of glycemic food (as hydro-electrolytic beverages, breads etc), to favor carbohydrate replacement.

Lipid intake should not be higher than $30 \%$ of the overall energetic value. The role of lipids for performance of physical activity is as reserve energy only ${ }^{20}$. The athletes of our sample had a lipid intake of $32 \%$ of the overall energetic amount, higher than the ideal proportion.

Furthermore, in accordance with ADA and CDA (American Dietetic Association and The Canadian Dietetic Association $)^{20}$, vitamins and minerals have an important role in the metabolism of macronutrients. If energetic and protein intake is adequate, probably there will be no inadequacies in the intake of these micronutrients.

According to "The National Institutes of Health Consensus Development Conference Statement Optimal Cal-

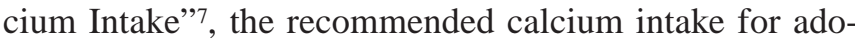
lescents and young adults with age ranging between 15 and 24 years is around 1,200-1,500 mg/day, and the current American recommendation is of $1,300 \mathrm{mg} /$ day for female adolescents. Adolescents have an increased need of calcium, particularly for growth, and it is the time of life $50 \%$ of the bony body mass is acquired, as it is fully formed by the age of 18 , approximately, and $37 \%$ of its development takes place during the growth stretch ${ }^{24}$.

Dietary studies show that adolescents, particularly females, do not intake appropriate amounts of this mineral. In the years of 1977 and $1978^{24}$, it was estimated that calcium intake among female adolescents was of about 799 $\mathrm{mg} / \mathrm{day}$, and that intake of food rich in calcium decreases with age.

The studied athletes had a daily intake of $1,204 \mathrm{mg} /$ day. Current American recommendation ${ }^{14}$ is of $1,300 \mathrm{mg} / \mathrm{day}$. When this amount is compared to the daily intake of these athletes, one can see a 92\% adequacy of current recommendation. Low calcium intake can be explained by little intake of mild and dairy food, which are sources of calcium, as only 11 of the studied athletes drank milk daily, $44 \%$ of the total (table 5). Low calcium intake at growth stage can lead to adverse effects in bone growth and bone mass peak ${ }^{14}$.

According to Gimmston et al. ${ }^{25}$, volleyball is a sport of impact, as it produces a reaction power by hitting the ground 3 to 6 times the body mass power. Volleyball players present a higher bone density than non-players of the same age, particularly hips and lumbar spine. We suggest that our volleyball players may have higher need of calcium, due to the physiologic moment they are undergoing, and the type of sport they practice ${ }^{25}$.

Iron-trace is a mineral that directly influences athletes' performance. Female athletes should pay special heed in iron intake, particularly due to losses that take place with menses. Iron deficiency also directly influences athletes' physical performance ${ }^{17}$.

The investigated players had an iron intake higher than the recommended for their age, being $188 \%$ of the American recommendation for non-athlete individuals ${ }^{13}$.

The assessed athletes had a zinc intake of $13.23 \mathrm{mg} /$ day, being the ideal amount of $12 \mathrm{mg} /$ day (NRC/RDA, 1989). Zinc is present in animal products, and their intake of beef and chicken was high, therefore not adequate.

B-complex vitamins are directly related to energetic intake, and the highest the energetic intake is, the more one should use these vitamins. The athletes had an adequate intake of these vitamins, due to high energetic consumption $^{26,27}$.

Due to low-protein intake and high turnover rate, there may be an increased need of vitamin $\mathrm{B}_{6}{ }^{18}$. Athletes had an average vitamin $B_{6}$ intake of $15.44 \mathrm{mg} / \mathrm{d}$, being higher than the current American recommendations of $12 \mathrm{mg} / \mathrm{d}^{28}$.

The amount of folate intake by the athletes is $50 \%$ higher than the ideal amount ${ }^{14}$. The amount of ingested folate ranged from 39 to $463 \mathrm{mg} /$ day, median of $200 \mathrm{mg} /$ day, much lower than current American recommendations. This nutrient seems to be at risk in these athletes diet, and the intake of dark-green leaves and fruits like oranges, strawberries, kiwi and avocado should be encouraged.

Vitamin $\mathrm{C}$ is involved in a number of metabolic reactions, acts on the synthesis of collagen, is related to immunologic function, and increases absorption of non-heme iron, preventing iron-deficiency anemia, and is an effective anti-oxidant ${ }^{26,27}$. The athletes had an adequate intake of vitamin C, according to IM/DRI (2000) (Institute of Medicine/Dietary Reference Intake) ${ }^{28}$, with daily ingestion of $100 \mathrm{mg}$.

Intake of vitamin $\mathrm{E}$ was of $11 \mathrm{mg} /$ day, being inadequate for age and gender, particularly of athletes. The ingested amount is $71 \%$ of the current recommendation ${ }^{20}$.

The athletes had a low intake of calcium, folate and vitamin E, compared to NRC/RDA (1989) ${ }^{13}$ and Monsen's guidelines $(2000)^{20}$. However, one cannot state that our athletes have an inadequate intake of these nutrients, as the method for dietary assessment, a 3-day food-intake record, in spite of being broadly used for dietary assessments, presents limitations of use, as it depends on cooperation of subjects, skill to estimate amounts, and changes in nutritional behavior over the recording process time. Some specialists also believe inadequate intake of vitamins and min- 
erals may also be due to incomplete information from nutrition tables and software.

According to $\mathrm{ADA}^{29}$, diets of some youth athletes, particularly females, are poor in energy and nutrients. As dietary recommendations for adolescents intend to favor growth and development, their practice of competitive sports enhances the role of diet for these athletes.

According to Fleck ${ }^{19}$, who used the same protocol in his study, the ideal percentage of body fat for youth female volleyball athletes is of $19 \%$. The athletes in our investigation presented a fat proportion of $20.5 \%$, corresponding to $108 \%$ of the amount for that type of physical activity. This author mentions that athletes of sports such as volleyball, basketball and rowing have a fat-free body mass higher than athletes of other sport modalities.

We have not found in the literature data on circumference measurements for volleyball athletes. These anthropometric measures were performed for a more detailed assessment of our athletes.

The athletes we investigated had weight and height similar to those of other studies ${ }^{19,29}$.

High stature, power, speed, motor coordination and jumping performance are features volleyball athletes should present. It is suggested that to enhance performance, volleyball athletes should have a low proportion of body fat ${ }^{2,6}$.

\section{CONCLUSION}

Young athletes should be advised on the importance of dietary adequacy for health and performance improvement. Many young athletes are influenced by misinformation provided by coaches, family members, friends and the media.

To enhance performance, athletes should reduce the proportion of body fat and increase the lean mass, through a balanced diet and increase of physical activity.

One should show to athletes, coaches and family member the importance and benefits of a proper diet. It is to be stressed the need of further investigations on dietary assessment for youth athletes of different sports modalities.

All the authors declared there is not any potential conflict of interests regarding this article.

\section{REFERENCES}

1. Borsari JR. História e regras. In: Voleibol: aprendizagem e treinamento, um desafio constante. 1a ed. São Paulo: Editora EPU, 1989;3-4.

2. Schutz LK. Volleyball. Phys Med Rehabil Clin N Am 1999;10:19-34.

3. Thompson JL. Energy balance in young athletes. Int J Sport Nutr 1998; 8:160-74.

4. Champan P, Toma RB, Tuveson RV, Jacob M. Nutrition knowledge among adolescent high school female athletes. Adolescence 1997;32:437-46.
5. Elmadfa I, Rupp B. Nutritional status of young athletes. Bibl Nutr Dieta 1994;51:S163-5.

6. Morrow JR, Jackson AS, Hosler WW, Kachurik JK. The importance of strength, speed and body size for team success in women's intercollegiate volleyball. Res Q Exerc Sport 1979;50:429-37.

7. Tobelmann RC. Estimated dietary calcium intake and food sources for adolescent females. J Adolesc Health 1997;20:S20-6.

8. Viviani F, Baldin F. The somatotype of "amateur" Italian female volleyball-players. J Sports Med Phys Fitness 1993;33:400-4.

9. Bernadot D. Working with young athletes: view of nutritionist on sports medicine team. Int J Sport Nutr 1996;6:110-20.

10. Garry PL, Koehler. Problemas de la interpretación de los datos dietéticos y bioquímicos obtenidos en estudios de población. In: Conocimientos actuales sobre nutrición. $6^{\text {th }}$ ed. Washington DC: ILSI Press, 1991; 471-9.

11. Pinheiro AB, Lacerda EM, Benzecry EH, Gomes MC, Costa VM. Tabela para avaliação de consumo alimentar em medidas caseiras. 4a ed. [s.n.], Rio de Janeiro, 1998.

12. Centro de Informática em Saúde da Escola Paulista de Medicina. Sistema de Avaliação Nutricional de São Paulo. Versão 2.5, 1993.

13. Institute of Medicine, Food and Nutrition Board, Dietary reference intake, for thiamin, riboflavin, niacin, vitamin $\mathrm{B}_{6}$, folate, vitamin $\mathrm{B}_{12}$, pantothenic acid, biotin, and coline. Washington D.C.; National Academy Press, 1998.

14. National Research Council - Recommended dietary allowances, $10^{\text {th }}$ ed. Washington DC: National Academy Press, 1989;284.

15. Pao EM, Cypel YS. Cálculo de la ingesta alimentaría. In: Conocimentos actuales sobre nutrición. 7a ed. North America; ILSI Press, 1999;53141.

16. Dwyer J. Avaliação do consumo alimentar. In: Shils ME, Olson JA, Shike M, Ross AC, editors. Tratado de nutrição moderna na saúde e na doença. 9a ed. Manole, 2001;1001-26.

17. Ainsworth B, Haskel WL, Leon AS, Jacobs DR, Montoye HJ Jr, Sallis JF, et al. Compendium of physical activities: classification of energy costs of human physical activities. Med Sci Sports Exerc 1992;25:7180 .

18. Fernandes JF. Avaliação antropométrica. In: A prática da avaliação física. Rio de Janeiro: Shape,1999;24-32.

19. Fleck SJ. Body composition of elite American athletes. Am J Sports Med 1983;11:S398-403.

20. Position of the American Dietetic Association and Canadian Dietetic Association: Nutrition for physical fitness and athletic performance for adults. J Am Diet Assoc 1993;93:691-6.

21. Lemon PWR. Dietary protein requirements in athletes. Nutr Biochem 1997;8:52-60.

22. Jacobs KA, Sheman WM. The efficacy of carbohydrate supplementation and chronic high carbohydrate diets for improving endurance performance. Int J Sport Nutr 1999;8:92-115.

23. Ribeiro BG, Pierucci APTR, Soares EA, Carmo MGT. A influência dos carboidratos no desempenho físico. Rev Bras Med Esporte 1998;4:197-202.

24. Morgan KJ. Magnesium and calcium dietary intakes of the US population. J Am Coll Nutr 1985;4:195-206.

25. Alfredson H, Norström P, Lorentzon R. Bone mass in female volleyball players and nonactive females. Calcif Tissue Int 1997;60:338-42.

26. Armstrong EL, Meresh CM. Vitamin and mineral supplements as nutritional aids to exercise performance and health. Nutr Rev 1996;54:149-58.

27. Rokitzki L, Sagredos A, Keck E, Sauer B, Keul J. Assessment of vitamin $B_{2}$ status in performance athletes of various types of sports. Int $J$ Sports Med 1994;15:435-40.

28. Monsen E. Dietary reference intakes for the antioxidant nutrients: vitamin C, vitamin E and carotenoides. J Am Diet Assoc 2000;100:637-64.

29. Häkkinen K. Changes in physical fitness profile in female volleyball players during the competitive season. J Sports Med Phys Fitness 1993; 33:S223-32. 